\title{
Service to the Community by the Civil Aparature of the Country (ASN) in Murung Raya District
}

\author{
Albert Aswin Yamada ${ }^{*}$, Asmaji Darmawi, Jamal Uddin \\ Master Program of Government Science, Lambung Mangkurat University, Banjarmasin, Indonesia
}

DOI: $10.36348 /$ sijlcj.2020.v03i06.004

| Received: 29.05.2020 | Accepted: 06.06.2020 | Published: 12.06.2020

*Corresponding author: Albert Aswin Yamada

\section{Abstract}

The behavior of the State Civil Apparatus towards service to the community in the People's Welfare Administration Section of the Murung Raya Regency Secretariat was identified in general with the impression of never being efficient, slow, convoluted and favoritism, this made possible work discipline and lack of ability and culture/habits of the community which deals every day. This study aims to determine the behavior of the State Civil Apparatus (ASN) Administrative Section of People's Welfare in Providing Services to Communities in Murung Raya Regency. This research is a descriptive study with a qualitative approach. Data obtained through interviews, observations, and literature reviews, and analyzed with interactive models.

Keywords: Behavior, State Civil Apparatus, Public Services.

Copyright @ 2020: This is an open-access article distributed under the terms of the Creative Commons Attribution license which permits unrestricted use, distribution, and reproduction in any medium for non-commercial use (NonCommercial, or CC-BY-NC) provided the original author and source are credited.

\section{Preliminary}

In the current era of globalization, one of the big challenges faced by the government, especially the local government, is how to present the State Civil Apparatuses who are professional, have good behavior, and meet the aspirations of the community. Those challenges are reasonable considering that empirically the people in the regions want Government officials to carry out their duties. The tasks can work optimally which ultimately can provide good service to the community [1].

In line with the community's need for quality services from the Government, one of the important aspects of quality service and satisfying the community depends on the Government. Because good behavior will also affect the service [2]. Good governance which is the functions of government itself, State is obliged to serve every citizen to fulfill their basic rights and needs in the framework of public services which are mandated by the 1945 Constitution.

The Regency Government through agencies/work units Office / Agency / Office, wherein the framework of carrying out the fields of Government, Development and community development is the front pillar/door in providing services to the community and channeling policies from the Government thereon as well as implementing it is also expected to provide good services in accordance from the policies and demands of the community itself.

The State Civil Apparatus must be a channel and a bridge in carrying out the public interest with full dedication and loyalty rather than vice versa, in carrying out its duties and functions Government officials must be responsive to changes that occur at any time among the community, nation, and State. Each apparatus needs to be aware of the goals of the State and be patient with the general public, which requires service by the apparatus with their respective duties and functions. Services to the community can be categorized as effective if the community gets the ease of service with a quick, precise, and satisfying procedure [3,4]. Success in service depends on the behavior of the apparatus in providing services to the public.

With the enactment of Law Number 25 of 2009 concerning Public Services, it is mandated that the Regional Government is obliged to improve the quality and guarantee the provision of public services following the general principles of good governance and corporation and to provide protection for every citizen and population from abuse of authority in the administration of public services relating to the basic needs of the community $[5,6]$. 
To find out the extent to which public services have been able to meet the expectations of the community in an area, efforts are needed to always improve services so that they are following the times and expectations of the community at this time. One form of evaluation of public service improvement is to survey the Community Satisfaction Index (IKM) [7].

\section{RESEARCH METHODS}

To obtain a clearer understanding of events and events in the provision of services to the community, this study uses a qualitative approach. The basic considerations besides the approach are loose and holistic [8]. This type of research according to the level of explanation is descriptive in depth (thick description) which seeks to explore and clarify a phenomenon or social reality by describing several variables related to the problem and unit under study [9].

Each event provides its perspective so that in each activity, sufficient data are reintegrated through its categories, units, and regions by tracing its theme which will eventually reach a solid conclusion. The main data sources in qualitative research are words and the rest of the action is additional data such as documents and others [10]. This opinion leads researchers to obtain the true meaning of the problem under study.

This type of research does not question the interwoven relationships between existing variables and does not test hypotheses, but only describes deeply an object of research at present based on facts that seem as they are [11]. Primary data is a source of data obtained directly from the source (not through intermediary media). Primary data can be in the form of individual or group subject opinions, observations of objects (physical), events or activities, and test results [12]. The research subjects were determined using a purposive technique consisting of:

a) Head of the Murung Raya Regency Secretariat for People's Welfare Administration

b) Head of Sub Division of Social Welfare Development and Community Organization Section of People's Welfare Administration Regional Secretariat of Murung Raya Regency

c) Head of Religious and Cultural Sub-Division of People's Welfare Administration, Murung Raya Regency Secretariat

d) Staff / Honorary at the People's Welfare Administration Section of the Murung Raya Regency Secretariat

e) Religious Leaders, Community Leaders, Customary Leaders, and Murung Raya Regency community

Data collection techniques and steps taken by researchers in data collection are as follows; 1) Direct interviews by researchers and respondents using an interview guide (interview guide), 2) Observations are used to see and explore the state of the State Civil
Service (ASN) Behavior in the People's Welfare Administration Section in Providing Services to the Community in Murung Raya Regency, and 3) Documentation in the form of written sources such as books, scientific magazines, archives, personal documents, and official documents of related parties [13].

In analyzing a data special attention is needed because from this step will determine the results to be presented, with the analysis of the data obtained will be able to provide a descriptive description of the focus of research. Miles \& Huberman [14] suggested three stages that must be done in analyzing qualitative research data, namely (1) data reduction; (2) data exposure (data display); and (3) conclusion drawing and verification (conclusion drawing/verifying). Data validity (validity) is carried out utilizing Data Triangulation and Theory Triangulation [13]. Data triangulation is comparing and checking both the degree of trust of information obtained through time and different ways by comparing the results of observations and interviews,

\section{RESULTS AND DISCUSSION}

Murung Raya Regency is one of the regencies in Central Kalimantan Province which is located in the interior of the island of Borneo and is located in the equatorial region, which is in the position $113^{\circ} 12$ '40.98 "- $115^{\circ} 8^{\prime}$ ' 6.25" East longitude and $0^{\circ} 51$ '51, 87 "LS - $0^{\circ} 47$ '25.24" LU, with regional boundaries including in the north bordering West Kalimantan and East Kalimantan Provinces, in the south bordering North Barito, Kapuas and Gunung Mas in the east bordering The provinces of East and West Kalimantan are bordered by Gunung Mas Regency and West Kalimantan Province. The area of Murung Raya Regency is approximately $23,700 \mathrm{Km} 2$ and consists of 10 Districts and 115 Villages and 9 Kelurahan. In general, Murung Raya Regency from the south to the east is a rather low plain, while to the north with the form of a hilly area folds, fractures explored by the Muller / Schwaner mountains. Part of the area with a slope of $0-2 \%$ is located in the southern part of the bank of the Barito River, part of the area with a slope of 2$15 \%$ spread in all districts covering an area of 1,785 $\mathrm{Km}^{2}(21.5 \%)$.

Parts of the region with a slope of $15-40 \%$ are spread in all districts covering 4,275 $\mathrm{km}^{2}(51.5 \%)$ and parts of areas with slopes above $40 \%$ covering 2,075 $\mathrm{km}^{2}(25 \%)$. The river in Murung Raya Regency is the Barito River which is in line with the North Barito Regency with a river length of approximately $900 \mathrm{Km}$ and an average width of $8 \mathrm{~m}$ which empties into the Java Sea. According to the state of the region, Murung Raya Regency consists of hilly land with an altitude above sea level between $123-700 \mathrm{~m}$. While the lowlands in the southern part stretch approximately $150 \mathrm{~km}$ to the north and is a soil with a degree of acidity of less than 7 . On 
the left and right side of the lowlands consists of plateaus, hills, mountain folds, and faults, there is the presence of red soil, yellow and sediment parent rocks, igneous rocks and other rocks.

Murung Raya Regency is in charge of 10 subdistrict areas consisting of 115 villages and 9 wards. Based on the legal status of the village in Murung Raya, the definitive village is 124 units or 100 percent. Referring to the PMD criteria of the Ministry of Home Affairs where villages are classified as self-sufficient (traditional), Swakarya (transitional), and Self-sufficient (developing) villages. The Murung Raya Regency Government in 2013 was strengthened by 3,285 Civil Servants, divided by 1,785 men and 1,567 women. Of the total civil servants are dominated by civil servants with a Bachelor's level of education followed by a PNS Diploma. This is a very good foundation for quality service to the community.

Murung Raya's economy is generally dominated by the primary sector, namely the agricultural sector and the mining and quarrying sector. In 2007 the agricultural sector was more dominant than the mining and quarrying sector. The mining and quarrying sector began to shift first positions from 2008 to 2012 .

The role of the agricultural sector on Murung Raya's economy until 2012 continues to decline. Prohibition of land burning is suspected as a factor causing this decline because the people of Murung Raya are accustomed to burning land to open new agricultural land. One of the subsectors that are quite dominant in the agricultural sector is a plantation with rubber as its commodity. Plantation sub-sector production continues to increase from year to year, but the increase is not as large as growth in the mining sector so that agriculture remains in second place.

The poverty level is a reflection of the quality of people's lives and a measure of the success of regional development. From 2005 with a poverty rate of 10.24 percent until 2012 poverty in Murung Raya continued to fall to 5.78 percent. This is inseparable from the success of the development programs that are carried out, therefore programs that are well-targeted and effectively effective need to be continued.

\begin{tabular}{|l|l|l|l|}
\hline Year & \multirow{2}{*}{ Poverty Line } & \multicolumn{2}{|l|}{ Poor Population } \\
\cline { 3 - 4 } & & Amount & Percentage \\
\hline$(1)$ & $(2)$ & $(3)$ & $(4)$ \\
\hline 2005 & 136,661 & 9800 & 10,24 \\
\hline 2006 & 153,539 & 8936 & 11.24 \\
\hline 2007 & 164,753 & 8683 & 8.91 \\
\hline 2008 & 210,392 & 8030 & 7.95 \\
\hline 2009 & 210,392 & 7190 & 6,94 \\
\hline 2010 & 272809 & 6900 & 6,55 \\
\hline 2011 & 291,433 & 6236 & 6.30 \\
\hline 2012 & 320,856 & 5870 & 5.78 \\
\hline 2013 & 353,373 & 6768 & 6,44 \\
\hline
\end{tabular}

Source: National Socio-Economic Survey, Central Bureau of Statistics, Murung Raya Regency

The Murung Raya Regency People's Welfare Administration Division was formed based on Regional Regulation (Perda) No. 13/2008 concerning the Tasks, Principles, and Duties of the Murung Raya Regency Secretariat. The People's Welfare Section is a staff element led by the Head of the People's Welfare Chart with Echelon III / a who is domiciled and is responsible for Assistant II in charge of Development and People's Welfare. Head of People's Welfare oversees 3 (three) Heads of Subdivisions namely:

1. Head of Sub Facilities of Worship, Religious Education and Religion with Echelon IV/a

2. Head of Sub Division of Religious Institutions and Community Development

3. Religious with Echelon IV / a

4. Head of Section for Grant Administration and Social Assistance Facilitation with Echelon IV / a
Based on the regulation, the People's Welfare Division has the following main tasks and functions:

1. Duty; Carry out the preparation of programs and guidelines for fostering administration of people's welfare, social, family and religious empowerment

2. The job description is as follows:

a. Assist Field Development Assistant in their area of work.

b. Gather materials for developing guidelines and technical guidelines for developing annual work programs and giving consideration to the Secretary and the Regent through the Assistant corresponding field of duty.

c. Collecting, estimating, and analyzing data in their area of work.

d. Planning a program of carrying out tasks in the field of Administration People's Welfare is based on existing data and information sources as a basis for implementing. 
e. Activities following applicable laws and regulations.

f. Lead activities according to RASK / DASK.

g. Guide and guide the head of the Subdivision in the Public Welfare Administration.

h. Consider the Regional Secretary and Regent through the Development Assistant.

i. Coordinate the preparation of programs and technical guidance for monitoring and monitoring the distribution of aid and the development of social service activities.

j. Report/account for smoothness carrying out tasks in the Administration of People's Welfare.

k. Lead a staff meeting to convey the necessary instructions from the leader/assistant to be known and followed up for the smooth implementation of service duties.

1. Supervise, monitor, evaluate, and control the activities of the Head of Subdivision.

m. Carry out coordination and collaboration with other relevant agencies in activities that have to do with the task field.

n. Guiding and giving instructions to the Head of Subdivision who is under him and provide an assessment of DP3 / SKP every year to all Head of Subdivisions under him.

\section{CONCLUSION}

Behavior of the State Civil Apparatus (ASN) Administration Section of People's Welfare in Providing Services to the Community in Murung Raya Regency can be concluded as follows; 1) Behavior of public service delivery in the People's Welfare Administration section of the Murung Raya Regency Government is related to the simplicity of service procedures, including easy and uncomplicated. 2) Public perception of the implementation of public services in the Administration of the People's Welfare Murung Raya Regency Government related to the principle of clarity of technical and administrative requirements is still unclear, for users of services who are the first time using services are still confused. 3) Behavior towards the administration of public services in the Administration of the People's Welfare Administration of the Murung Raya Regency Government related to employee responsibilities in resolving complaints classified as responsibility for their duties. 4) The behavior of public services in the Administration of the People's Welfare Murung Raya District Government related to hospitality and politeness, overall classified as friendly and polite, although there are still some of the unscrupulous employees in terms of quality of service to the community, although overall it is quite good. Placement of signs to the administration section should be placed in a strategic and clear location. However, it is necessary to make an information board that contains clearer administrative requirements and the addition of special information section employees.

\section{REFERENCES}

1. Agus, D. (2005). Mewujudkan Good Governance Melalui Pelayanan Publik. Yogyakarta: Gajah Mada University Press.

2. Ratminto., \& Winarsih, A. S. (2010). Manajemen Pelayanan. Yogyakarta: Pustaka Belajar.

3. Mulyana, D. (2005). Ilmu Komunikasi: Suatu Pengantar. Bandung: PT. Remaja Rosdakarya.

4. Rakhmat, J. (2011). Psikologi Komunikasi. Bandung: PT. Remaja Rosdakarya.

5. Widodo, J. (2001). Etika Birokrasi dalam Pelayanan Publik. Malang: CV. Citra Malang.

6. Moenir, A. (2008). Manajemen pelayanan Umum di Indonesia. Jakarta: Bina Aksara.

7. Sinambela, L. P. (2008). Reformasi Pelayanan Publik. Jakarta: Bumi Aksara.

8. Neuman, W. L. (2015). Metodologi Penelitian Sosial: Pendekatan Kualitatif Dan Kuantitatif. Jakarta: PT Indeks.

9. Iskandar. (2008). Metodologi Penelitian Pendidikan dan Sosial (Kuantitatif dan. Kualitatif). Jakarta: GP Press.

10. Mohammad. (2008). Metode Penelitian Kuantitatif-Kualitatif. Malang: UIN.

11. Syaodih. (2012). Metode Penelitian Pendidikan. Bandung: PT. Remaja Rosdakarya.

12. Saebani, A. D. (2009). Metodologi Penelitian Kualitatif. Pustaka Setia: Bandung.

13. Moleong, L. J. (2002). Metode Penelitian Kualitatif. Bandung: PT Remaja Rosdakarya.

14. Miles, M. B., \& Huberman, A. M. (1992). Analisis data kualitatif. 